\section{Is retirement associated to greater life satisfaction? Cross-sectional findings from ELSA-Brasil}

\author{
A aposentadoria está associada a maior satisfação \\ com a vida? Achados transversais do estudo \\ ELSA-Brasil
}

Jôsi Fernandes de Castro Rodrigues 1

Sandhi Maria Barreto 1

Rosane Harter Griep 2

Maria de Jesus Mendes da Fonseca ${ }^{3}$

Lidyane do Valle Camelo 1

Luana Giatti 1

doi: 10.1590/0102-311X00034521

\begin{abstract}
This study aimed to examine whether retirement is associated with greater life satisfaction and if this association differs by sex and type of work. This is a cross-sectional analysis of 13,645 active and retired civil servants, attending to the second visit of the Brazilian Longitudinal Study of Adult Health cohort (ELSA-Brasil, 2012-2014). Retirees due to disability were excluded. The explanatory variables were: (1) current occupational status (not retired, retired); (2) work engagement after retirement (not retired, retired and working, retired and not working); (3) time since retirement (not retired, >0-3, > $3-8,>8-15,>15$ years). Life satisfaction was obtained from the Satisfaction With Life Scale. Associations were estimated by multiple linear regression. After considering sociodemographic and health indicators, life satisfaction was higher for retired individuals $(\beta=0.50,95 \% C I: 0.32 ; 0.68)$ than not retired. Retirees who were not working $(\beta=0.56,95 \% \mathrm{CI}: 0.33 ; 0.78)$ seemed to be more satisfied than those working ( $\beta=0.46,95 \% \mathrm{CI}$ : $0.26 ; 0.66)$. Life satisfaction was greater among those who retired: $>0-3$ years $(\beta=0.57,95 \%$ CI: 0.33 ; $0.81),>8-15$ years $(\beta=0.66,95 \% \mathrm{CI}: 0.34 ; 0.98)$, and $>15$ years $(\beta=0.51$, $95 \%$ CI: $0.27 ; 0.74)$ as compared to active workers. These associations were not modified by gender or type of work. In this Brazilian cohort, retired civil servants from teaching and research institutions seemed to be more satisfied with their lives than active individuals. Results suggest that life satisfaction may vary with time after retirement and whether individuals keep working afterwards, although the variations overlap.
\end{abstract}

Retirement; Work; Personal Satisfaction; Cross-Sectional Studies

\author{
Correspondence \\ L. Giatti \\ Faculdade de Medicina, Universidade Federal de Minas Gerais. \\ Av. Alfredo Balena 190, Belo Horizonte, MG 30130-100, Brasil. \\ luana.giatti@gmail.com \\ 1 Universidade Federal de Minas Gerais, Belo Horizonte, Brasil. \\ 2 Instituto Oswaldo Cruz, Fundação Oswaldo Cruz, Rio de \\ Janeiro, Brasil. \\ 3 Escola Nacional de Saúde Pública Sergio Arouca, Fundação \\ Oswaldo Cruz, Rio de Janeiro, Brasil.
}




\section{Introduction}

Life satisfaction, a global appreciation of life, is a cognitive component of subjective well-being 1. It is influenced not only by the social, political, economic, and cultural contexts, but also by individual factors, such as occupational status 2 . Evidence indicates an association between life satisfaction and a better general health 3 and greater longevity 4 .

Population aging and the ever-growing longevity are worldwide phenomena. The Brazilian population is aging very quickly, with some estimations suggesting that one in four Brazilians will be over 65 years of age in 2060 , and a large portion of older adults will be retired. Because retirement is a stage of life with multidimensional repercussions that can affect well-being and health, it has gained increased relevance for public health ${ }^{6}$.

Retirement is characterized by contradictory feelings, with potential implications for life satisfaction ${ }^{7}$. On one hand, the experience of retirement can foster well-being as workers retire from a demanding or stressful activity. On the other hand, the transition towards retirement can negatively affect well-being because one's disconnection from the labor force, reduction in the social network, and demise of work related identity ${ }^{8}$. These facts seem to contribute to the growing contingent of people who put off retirement or continue to work even after retirement 9 .

Studies investigating the association between retirement and life satisfaction have shown inconsistent results, indicating positive associations between retirement and greater life satisfaction 10,11, negative associations 8 or even absence of association 12. These inconsistencies can be partially explained by differences in the instruments used to measure life satisfaction 13, the type of retirement analyzed (voluntary/involuntary) 14 , the age of retirement 15 , and the institutional and prevailing circumstances of retirement 16 .

There are indications that the magnitude of the association between retirement and life satisfaction increases as the time after retirement increases 10. Furthermore, one's engagement in some job after retirement could positively influence life satisfaction, since it attenuates the difficulties to adjust to retirement. For example, retired older Brazilians who maintained some working activity showed greater life satisfaction than those who did not work after retirement 17.

The role of work in gender identity also tends to differ and to affect life satisfaction after retirement 18 . It is well-known that men and women have different experiences of subjective well-being, with women tending to report less well-being than men ${ }^{19}$. The characteristics of the occupation may also have implications in life satisfaction before and after retirement. Retirees from jobs with high levels of physical demand tend to report greater life satisfaction after retirement than those who retire from less physical-demanding jobs 10 .

This study aimed to investigate if retirement is associated with life satisfaction in a Brazilian cohort of civil servants (Brazilian Longitudinal Study of Adult Health - ELSA-Brasil). Three hypotheses were tested, all of which considered active workers as the reference category: (1) retired participants presented greater life satisfaction; (2) retirees who work report a greater life satisfaction than those who do not work; and (3) life satisfaction enhances with the increase in time after retirement. This study also tested whether the associations found differ according to sex and type of work.

\section{Methods}

\section{Data source and study population}

This study is a cross sectional analysis conducted with participants from the ELSA-Brasil who attended to the second visit of exams and interviews (2012-2014). ELSA-Brasil is a multicenter cohort of civil servants, aged 35-74 years at baseline (2008-2010), who were active and retired, from teaching and research institutions in 6 Brazilian capital cities. Data collection encompassed interviews and clinical exams conducted by trained and certified research assistants, using standardized procedures. Details of the study design and cohort profile can be found elsewhere 20,21. ELSA-Brasil was approved by the Research Ethics Committees of each institution involved, and by the Brazilian National Com- 
mission for Ethics in Research (CONEP 976/2006) of the Brazilian Ministry of Health. All participants signed the informed consent form.

In total, 14,014 (92.8\%) out of 15,105 baseline participants complied with the second visit [204 (1.3\%) died and 887 (5.9\%) missed the appointment]. Retirees due to disability at baseline $(\mathrm{n}=199)$ and at the second visit $(n=53)$, as well people with missing information on working/retirement situation $(\mathrm{n}=25)$, life satisfaction variable $(\mathrm{n}=79)$, or work after retirement $(\mathrm{n}=11)$ were excluded. Therefore, the analytical sample totaled 13,645 (97.4\%) individuals.

\section{Measures}

\section{- Life satisfaction}

The response variable, life satisfaction (total score), was measured by the Satisfaction With Life Scale 1, which was translated into and adapted for the Brazilian Portuguese. The scale contains five statements: "In most ways, my life is close to my ideal"; "The conditions of my life are excellent"; "I am satisfied with my life"; "So far I have gotten the important things I want in life"; "If I could live my life over, I would change almost nothing". For each of these statements, the response options varied from 1 (strongly disagree) to 7 (strongly agree). The life satisfaction total score varies from 5 to 35 ; the higher the score, the greater the life satisfaction, considered as a continuous variable.

\section{- $\quad$ Retirement status}

Three explanatory variables on working status, all ascertained at the date of the second visit, were considered:

(1) Current occupational status (not retired, retired): defined based on the answer to the question on whether they were currently working at the ELSA institution or had retired;

(2) Work engagement after retirement (not retired, retired and working, retired and not working): all participants that reported being retired and who also answered that were currently working were classified as "retired and working", otherwise they were regarded as "retired and not working";

(3) Time since retirement (not retired, $>0-3$ years, $>3-8$ years, $>8-15$ years, $>15$ years): the time since retirement was estimated by the subtraction "age at the second visit - age at retirement".

\section{Covariates}

Sociodemographic factors: sex (men, women), age-group (38-54, 55-59, 60-64, > 64 years), schooling level (complete higher education, complete high school, less than high school), quintile of per capita family income (1st quintile $=$ lowest and 5 th quintile $=$ highest), marital status (married/living with a partner, separated/divorced, single and widowed/widower), and type of work (not manual, manual). For active participants, the type of work was based on the current occupation, while for those who were already retirees at baseline, it was based on the most frequent occupation before retirement. Duration of work at the ELSA-Brasil institutions (in years) was categorized as $\leq 9,10-19,20-29$, $30-39, \geq 40$ years.

The health related covariates were: smoking (no, yes); leisure-time physical activity measured by the long version of the International Physical Activity Questionnaire (IPAQ) categorized as active, inactive (less than 150 minutes of moderate; less than 75 minutes of vigorous physical activity per week) 22; and weekly alcohol consumption (none, moderate, excessive), excessive consumption being defined as $\geq 210 \mathrm{~g}$ of alcohol among men and $\geq 140 \mathrm{~g}$ among women; body mass index (BMI, $\mathrm{kg} / \mathrm{m}^{2}$ ), a continuous variable in the analysis, and categorical (BMI: $18.5-24.9 \mathrm{~kg} / \mathrm{m}^{2}=$ eutrophic, $25-29.9 \mathrm{~kg} / \mathrm{m}^{2}=$ overweight, $>30 \mathrm{~kg} / \mathrm{m}^{2}=$ obese, $<18.5 \mathrm{~kg} / \mathrm{m}^{2}=$ underweight) for description; depression (no, yes), obtained with the Portuguese version of the Clinical Interview Schedule - Revised 23; and number of chronic conditions (none, one, two or more) defined by the sum of the number of medical diagnoses referred to at baseline embracing the following conditions (no, yes): hypertension, diabetes, myocardial infarction, heart failure, rheumatic fever, Chagas's disease, stroke, kidney disease, thrombosis or 
embolism, asthma, chronic obstructive pulmonary disease, problems with joints, cirrhosis or hepatitis, and cancer.

The variable "reasons for retirement" (age limit, length of work and other) was used to characterize the retired participants.

\section{Statistical analysis}

Descriptive analysis was based on proportions and means ( \pm standard deviation). The ANOVA test was used to verify differences in life satisfaction score means according to the explanatory variables.

The association between each explanatory variable and the mean life satisfaction score was estimated using multiple linear regression. After the crude analyses (Model 0) covariates were included as follows: age, sex (Model 1); schooling level, family income, type of work, and marital status (Model 2); smoking, physical activity, alcohol consumption, depression, number of chronic diseases and duration of work at the ELSA-Brasil institutions (Model 3). The adjustments for age, sex, marital status, type of work, and family income were maintained, regardless of the statistical significance, since they are established confounding factors for the investigated associations. The remained covariates were kept on the final model only if statistically associated with life satisfaction $(<0.05)$. Multicollinearity among variables was evaluated by the variance inflation factor (VIF) 24.

Multiplicative interactions between each of the retirement variables and sex or type of work were evaluated by the inclusion of interaction terms in the totally adjusted regression models.

The assumptions of homoscedasticity and normality of the residues in the final models were tested graphically. All analyses were performed using the Stata software, version 14 (https:// www.stata.com).

\section{Results}

Nearly $33 \%$ of the participants were aged over 60 years, most were female, had higher education, were married or living with a partner, and had a non-manual work. Approximately $10 \%$ of the participants were smokers, $8 \%$ informed excessive alcohol consumption, $73.6 \%$ were physically inactive, and $31.1 \%$ reported two or more chronic diseases (Table 1).

Overall, the most common reason for retirement (70\%) was employment duration. This proportion was similar among retirees who worked and those who did not work, and somewhat higher for those with more than 15 years $(75.5 \%)$ since retirement (Table 2).

The mean life satisfaction score adjusted for age was higher for retirees $(24.38 \pm 0.07)$ than for the not retired (23.95 \pm 0.04$)$. The retirees who did not work had slightly higher life satisfaction mean $(24.42 \pm 0.10)$ than those who did work as compared to the not retired. Except for participants who retired $>3-8$ years ago, all the other times since retirement showed greater life satisfaction mean score than not retired, with the $>8-15$ years ago group presenting the highest mean score $(24.57 \pm 0.16)$ (Figure 1).

In the linear regression analysis, retirees presented a greater life satisfaction in both the crude ( $\beta=1.07,95 \%$ CI: $0.94 ; 1.20)$ and the fully adjusted models ( $\beta=0.50,95 \% \mathrm{CI}: 0.32 ; 0.68)$, when compared with the not retired (Table 3).

In the crude analysis, retirees that did not work ( $\beta=1.09,95 \%$ CI: $0.89 ; 1.29)$, as well as those who did work ( $\beta=1.07,95 \%$ CI: $0.91 ; 1.22)$, presented higher life satisfaction means than the not retired civil servants. After the adjustments, the regression coefficients reduced, but the observed associations remained statistically significant, being somewhat stronger for the retirees that did not work ( $\beta=0.56,95 \%$ CI: 0.33 ; 0.78) than for those who did work ( $\beta=0.44,95 \%$ CI: $0.24 ; 0.63)$, although the confidence intervals overlapped (Table 3 ). 
Table 1

Characteristics of the sample by retirement status. Brazilian Longitudinal Study of Adult Health (ELSA-Brasil), 2012-2014.

\begin{tabular}{|c|c|c|c|}
\hline Characteristic & $\begin{array}{l}\text { Overall (\%) } \\
{[n=13,645]}\end{array}$ & $\begin{array}{c}\text { Active (\%) } \\
{[n=10,094]}\end{array}$ & $\begin{array}{c}\text { Retiree (\%) } \\
{[n=3,551]}\end{array}$ \\
\hline \multicolumn{4}{|l|}{ Age (years) } \\
\hline $38-54$ & 49.1 & 64.7 & 4.7 \\
\hline $55-59$ & 18.5 & 20.1 & 13.9 \\
\hline $60-64$ & 15.3 & 11.2 & 26.9 \\
\hline$>64$ & 17.1 & 4.0 & 54.5 \\
\hline \multicolumn{4}{|l|}{ Sex } \\
\hline Men & 45.6 & 48.4 & 37.6 \\
\hline Women & 54.4 & 51.6 & 62.4 \\
\hline \multicolumn{4}{|l|}{ Schooling level } \\
\hline Complete higher education & 57.7 & 59.4 & 53.0 \\
\hline Complete high school & 31.2 & 32.3 & 28.3 \\
\hline Complete primary education & 6.1 & 4.8 & 9.7 \\
\hline Incomplete primary education & 5.0 & 3.5 & 9.0 \\
\hline \multicolumn{4}{|l|}{ Quintile of per capita family income } \\
\hline 5th (highest income) & 18.9 & 15.4 & 28.7 \\
\hline 4 th & 20.3 & 21.2 & 18.0 \\
\hline $3 r d$ & 19.7 & 20.8 & 16.6 \\
\hline 2nd & 20.4 & 21.4 & 17.6 \\
\hline 1st (lowest income) & 20.7 & 21.2 & 19.1 \\
\hline \multicolumn{4}{|l|}{ Marital status } \\
\hline Married/Lives with a partner & 65.4 & 67.6 & 59.3 \\
\hline Separated/Divorced & 16.0 & 16.0 & 16.2 \\
\hline Single & 13.7 & 13.4 & 14.4 \\
\hline Widowed & 4.9 & 3.0 & 10.1 \\
\hline \multicolumn{4}{|l|}{ Type of work } \\
\hline Not manual & 82.7 & 82.4 & 83.4 \\
\hline Manual & 17.3 & 17.6 & 16.6 \\
\hline \multicolumn{4}{|c|}{ Duration of work at the ELSA institution (years) } \\
\hline$\leq 9$ & 9.0 & 11.1 & 3.0 \\
\hline $10-19$ & 22.6 & 24.9 & 15.9 \\
\hline $20-29$ & 41.6 & 39.4 & 47.9 \\
\hline $30-39$ & 24.8 & 22.9 & 30.4 \\
\hline$\geq 40$ & 2.0 & 1.7 & 2.8 \\
\hline \multicolumn{4}{|l|}{ Smoking } \\
\hline No & 89.2 & 88.6 & 90.8 \\
\hline Yes & 10.8 & 11.4 & 9.2 \\
\hline \multicolumn{4}{|l|}{ Physical activity for leisure } \\
\hline Active & 26.3 & 26.2 & 26.9 \\
\hline Inactive & 73.7 & 73.8 & 73.1 \\
\hline \multicolumn{4}{|l|}{ Alcohol consumption } \\
\hline No & 34.5 & 33.0 & 39.0 \\
\hline Moderate & 57.4 & 58.6 & 53.9 \\
\hline Excessive & 8.1 & 8.4 & 7.1 \\
\hline
\end{tabular}

(continues) 
Table 1 (continued)

\begin{tabular}{lccc}
\hline Characteristic & $\begin{array}{c}\text { Overall (\%) } \\
{[\mathbf{n = 1 3 , 6 4 5}]}\end{array}$ & $\begin{array}{c}\text { Active (\%) } \\
{[\mathbf{n}=\mathbf{1 0 , 0 9 4}]}\end{array}$ & $\begin{array}{c}\text { Retiree (\%) } \\
{[\mathbf{n}=\mathbf{3 , 5 5 1}}\end{array}$ \\
\hline BMI & & & \\
Eutrophic & 31.6 & 31.9 & 30.9 \\
Overweight & 41.4 & 41.0 & 42.5 \\
Obese & 26.3 & 26.4 & 26.0 \\
Underweight & 0.7 & 0.7 & 0.6 \\
Depression & & & \\
No & 95.9 & 95.8 & 36.4 \\
Yes & 4.1 & 4.2 & 3.6 \\
Number of chronic diseases & & & 20.9 \\
0 & 34.0 & 38.5 & 32.3 \\
1 & 34.9 & 35.8 & 46.8 \\
$2+$ & 31.1 & 25.7 & \\
\hline
\end{tabular}

BMI: body mass index.

Table 2

Retirement status according to reasons for retirement. Brazilian Longitudinal Study of Adult Health (ELSA-Brasil), 2012-2014 $(\mathrm{N}=3,543)$.

\begin{tabular}{lccc}
\hline Retirement status & \multicolumn{2}{c}{$\begin{array}{c}\text { Reasons of retirement } \\
\text { Length of work }\end{array}$} & Other \\
& $\mathbf{n}(\%)$ & $\mathbf{n}(\%)$ & $\mathbf{n}(\%)$ \\
\hline $\begin{array}{l}\text { Current occupational status } \\
\text { Work engagement after }\end{array}$ & $583(16.5)$ & $2,502(70.6)$ & $458(12.9)$ \\
retirement & & & \\
$\quad$ Retiree and working & $383(16.5)$ & $1,642(70.6)$ & $300(12.9)$ \\
$\quad$ Retiree and not working & $200(16.4)$ & $860(70.6)$ & $158(13.0)$ \\
Time since retirement (years) & & & \\
$>0-3$ & $220(23.3)$ & $621(65.9)$ & $102(10.8)$ \\
$>3-8$ & $45(27.8)$ & $101(62.3)$ & $16(9.9)$ \\
$>8-15$ & $137(26.9)$ & $324(63.7)$ & $48(9.4)$ \\
$>15$ & $181(9.4)$ & $1,458(75.5)$ & $292(15.1)$ \\
\hline
\end{tabular}

The results of the analysis, considering the time since retirement, did not indicate a clear pattern in the associations with life satisfaction. In the final model, when compared to not retired individuals, the life satisfaction mean scores were greater for time since retirement $0-3$ years $(\beta=0.57,95 \% \mathrm{CI}$ : 0.33 ; 0.81$)$; $>8-15$ years $(\beta=0.66,95 \%$ CI: $0.34 ; 0,98)$, and $>15$ years $(\beta=0.51,95 \%$ CI: $0.27 ; 0.74)$, with the coefficient being somewhat higher for the time of retirement of $>8-15$ years, whereas time since retirement of $>3-8$ years was not statistically associated with life satisfaction $(\beta=-0.34,95 \% \mathrm{CI}$ : -0.86 ; 0.17) (Table 3).

We found no evidence of statistically significant interactions between the explanatory variables and sex or type of work in any of the analyzed regression models.

Linearity and homoscedasticity were not violated in the final models presented herein. 


\section{Figure 1}

Means of life satisfaction score adjusted for categorical age by retirement status indicators. Brazilian Longitudinal Study of Adult Health (ELSA-Brasil), 2012-2014.

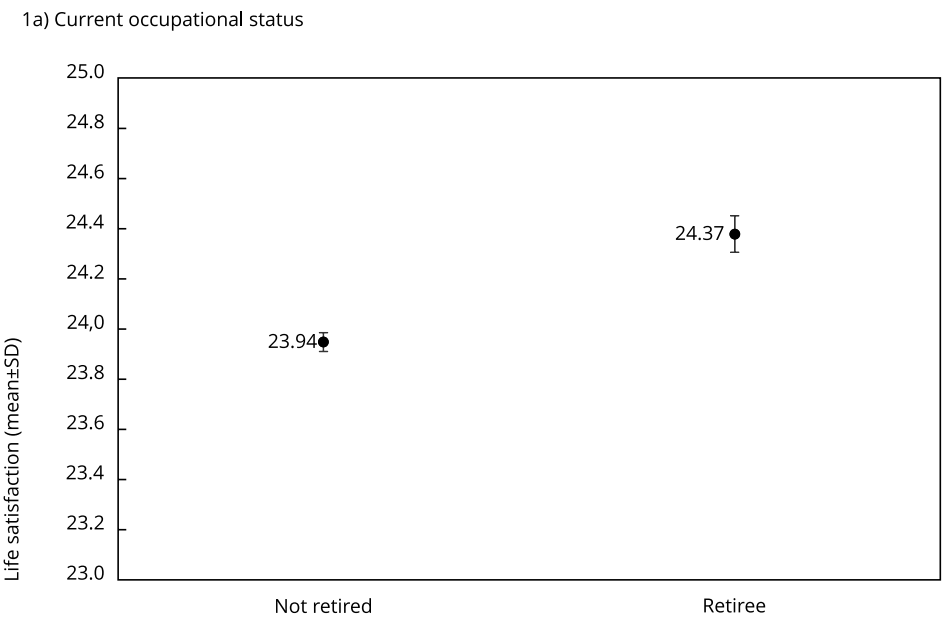

1b) Work engagement after retirement

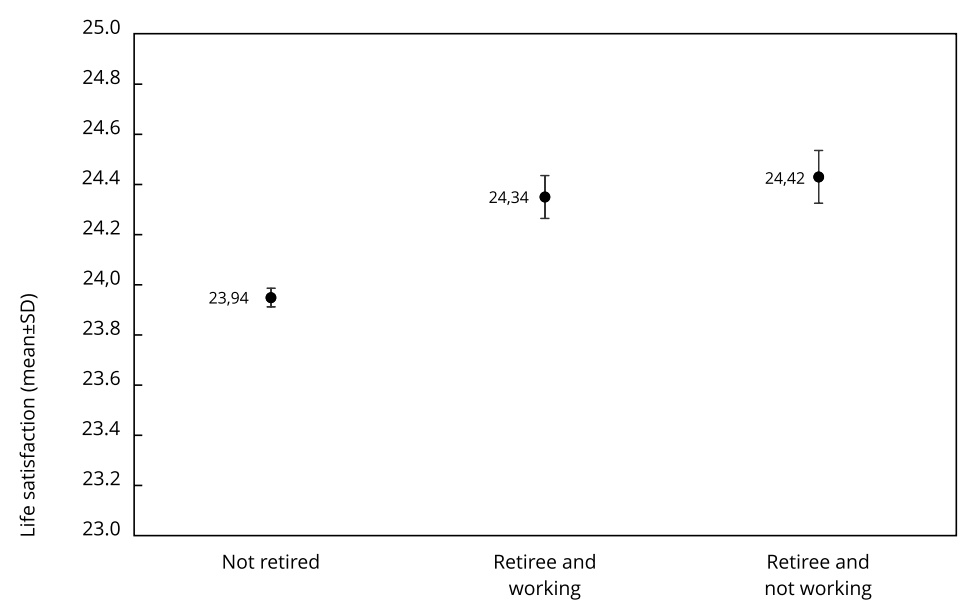

1c) Time since retirement (years)

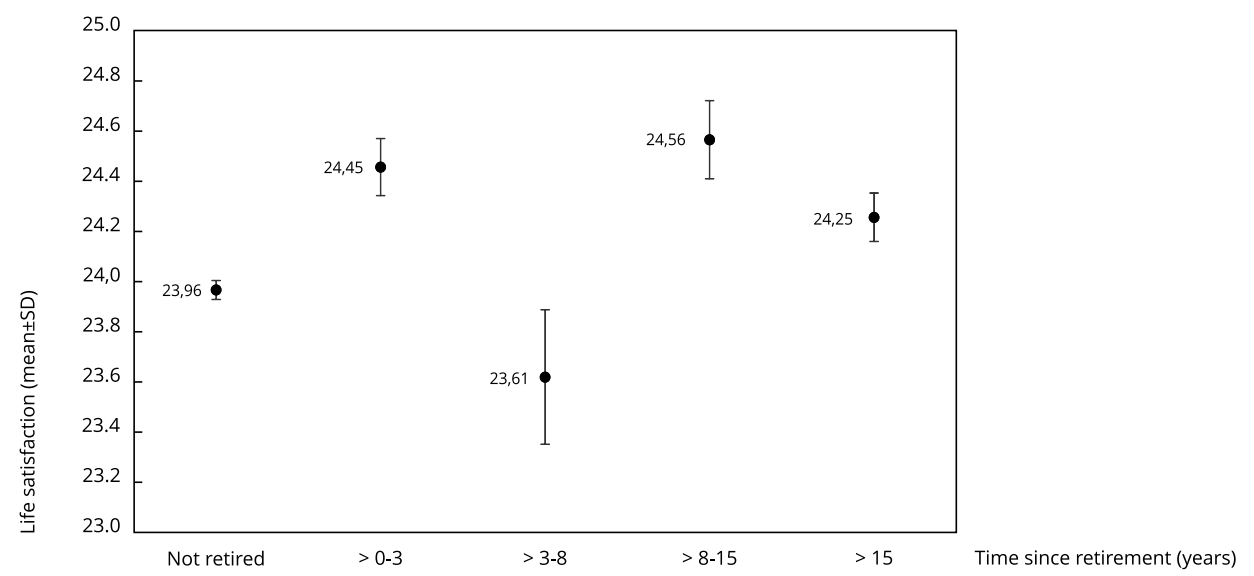

Note: ANOVA test: p-value $<0.0001$. 
Table 3

Associations of life satisfaction with retirement status. Brazilian Longitudinal Study of Adult Health (ELSA-Brasil), 2012-2014.

\begin{tabular}{|c|c|c|c|c|}
\hline Working status during the second visit & $\begin{array}{l}\text { Unadjusted } \\
\beta(95 \% \mathrm{CI})\end{array}$ & $\begin{array}{l}\text { Model } 1 \text { * } \\
\beta(95 \% \mathrm{Cl})\end{array}$ & $\begin{array}{c}\text { Model } 2 \text { ** } \\
\beta(95 \% \mathrm{Cl})\end{array}$ & $\begin{array}{c}\text { Model } 3 * * * \\
\beta(95 \% \mathrm{Cl})\end{array}$ \\
\hline \multicolumn{5}{|l|}{ Current occupational status } \\
\hline Not retired & Reference & Reference & Reference & Reference \\
\hline Retiree & $1.07(0.94 ; 1.20) \#$ & $0.50(0.33 ; 0.68) \#$ & $0.48(0.30 ; 0.65) \#$ & $0.50(0.32 ; 0.68) \#$ \\
\hline \multicolumn{5}{|l|}{ Work engagement after retirement } \\
\hline Not retired & Reference & Reference & Reference & Reference \\
\hline Retiree and working & $1.07(0.91 ; 1.22) \#$ & $0.48(0.28 ; 0.68) \#$ & $0.44(0.25 ; 0.64) \#$ & $0.46(0.26 ; 0.66) \#$ \\
\hline Retiree and not working & $1.09(0.89 ; 1.29) \#$ & $0.54(0.31 ; 0.77) \#$ & $0.52(0.30 ; 0.75) \#$ & $0.56(0.33 ; 0.78) \#$ \\
\hline \multicolumn{5}{|l|}{ Time since retirement (years) } \\
\hline Not retired & Reference & Reference & Reference & Reference \\
\hline$>0-3$ & $0.98(0.75 ; 1.21) \#$ & $0.54(0.30 ; 0.78) \#$ & $0.53(0.30 ; 0.77) \#$ & $0.57(0.33 ; 0.81) \#$ \\
\hline$>3-8$ & $0.16(-0.37 ; 0.69)$ & $-0.29(-0.82 ; 0.24)$ & $-0.32(-0.85 ; 0.20)$ & $-0.34(-0.86 ; 0.17)$ \\
\hline$>8-15$ & $1.25(0.95 ; 1.55) \#$ & $0.66(0.34 ; 0.98) \#$ & $0.60(0.28 ; 0.92) \#$ & $0.66(0.34 ; 0.98) \#$ \\
\hline$>15$ & $1.06(0.90 ; 1.23) \#$ & $0.37(0.15 ; 0.60) \#$ & $0.33(0.11 ; 0.55) \#$ & $0.51(0.27 ; 0.74) \#$ \\
\hline
\end{tabular}

95\% Cl: 95\% confidence interval.

Note: regression coefficients $\beta$ represent the difference in mean of life satisfaction score.

* Model 1: model adjusted for age (categorical) and sex;

** Model 2: Model 1 adjusted for schooling, per capita family income, nature of the occupation and marital status;

*** Model 3: Model 2 adjusted for smoking, physical activity, depression, number of chronic diseases and duration of work at the ELSA-Brasil institutions;

$\#$ p-value $<0.05$.

\section{Discussion}

Results from this large and multicenter cohort of Brazilian civil servants indicate that retirees have higher satisfaction with their lives than working individuals. We also observed that retirees who were not working were somewhat more satisfied than those who remained working, when compared to active civil servants. When time since retirement was considered, we found no indication of a pattern in the relation between time since retirement and life satisfaction. By taking not retired as the reference category, we observed slightly higher life satisfaction mean scores for retirees who retired 8-15 years ago and no association with time since retirement $>3-8$ years. None of the described associations were explained by sociodemographic characteristics, behavioral or health factors. Contrary to our initial hypothesis, the associations of life satisfaction with retirement, work engagement after retirement, and with time since retirement, did not differ according to gender or type of work.

Our results indicate that, on average, retirees - especially retirees that were not working - presented greater life satisfaction compared to those not retired, regardless of income and other covariables. To this date, we found no study comparing the life satisfaction of working and not working retirees with the life satisfaction of individuals who were active workers. Studies including only retirees, comparing people who did not work with those who did work, showed controversial results. A South Korean study with retirees found that those who did not work were more satisfied, on average, than retirees who remained working ${ }^{6}$. However, a study of retirees in Brazil showed lower life satisfaction among retirees that worked for financial reasons, as compared to those that remained retired 25. Another Brazilian study with older adults found that maintaining work activities after 65 years of age was associated with a greater life satisfaction, when compared to those who did not work, regardless of the social, demographic, and clinical characteristics, but the Brazilian study did not address the question of work after retirement 17. Results of studies with German and Swiss retirees also diverge from ours, as they showed that retirees who continued to work presented the greatest life 
satisfaction ${ }^{6}$. Similarly, in Holland, retirees that were not able to find a job after retirement showed less life satisfaction after retirement 26 .

Previous studies have highlighted the significance of socioeconomic resources for life satisfaction after retirement, because they limit the level of access to social and cultural resources that contribute to life satisfaction 16. A European study with data from 16 countries showed that life satisfaction after retirement was strongly associated with income, that is, among retirees with low income, working after retirement was associated with greater life satisfaction, but it was indifferent among retirees with higher pension incomes 27 . In our study, the adjustment for family income caused only a slight reduction in the magnitude of the association between the retirement status and life satisfaction, possibly due to the characteristics of the sample studied: stable civil servants with pensions equal to the salaries of active civil servants in the same category and institution.

Possibly, the greater autonomy to manage free time, added to the absence of work-related stress, may contribute to explain the greater life satisfaction of those retirees that did not work vis-à-vis those who did work, as compared to the active servants. For example, a systematic review of longitudinal studies showed that retirement had been repeatedly associated with an increase in time for leisuretime sports and physical activity 28 , and it is well-known that physical activity positively influences life satisfaction. On the other hand, engagement in postretirement work may be a way to avoid a disruptive transition out of the labor force and related changes in psychological well-being 29 , as well as in life satisfaction. Furthermore, non-monetary gains, like socialization or the need for mental stimulation, may give incentive for one's return to work 9.

The associations between time since retirement and life satisfaction indicate a positive association for the first 3 years after retirement, and for time of retirement greater than 8 years, while no association was found in the period from 3 to 8 years when compared to not retired participants. Somehow, this analysis corroborates previous investigations, such as the Health and Retirement Study panel, which suggested that the momentary positive effect of retirement on life satisfaction tends to increase in the long run 10. Results of the panel study from the United Kingdom indicated that immediately after transitioning to retirement, individuals were more satisfied with their life as compared to the period of up to three prior years, and although this association was attenuated, it persisted over time ${ }^{30}$. On the other hand, our findings diverge from a panel study from Germany, which did not identify an association between retirement and greater life satisfaction in the first 10 years after retirement 31 .

There are indications that the relation between the duration of retirement and life satisfaction is neither linear nor unidirectional 31 . A multi-stage adjustment to retirement has been portrayed, with new retirees undergoing a sort of honeymoon, followed by a reduction in life saytisfaction, and then a final stable period 15 . Our results neither support nor contradict the honeymoon theory, as newly retired were more satisfied than active workers, but not as much as those who retired $>3-8$ years ago. Positive changes in well-being during the early years of postretirement may reflect the retiree's release from the daily pressures of work 32 or satisfaction related to the relief from an unpleasant role at work 29. It is also possible that the newly retired benefit more from pre-retirement networks or social activities relating to work than those who retired long ago 33 . Furthermore, according to the life course perspective, after the transition stage, the postretirement trajectories will involve an overall adjustment towards stabilizing living conditions and routines 29 .

Differently from most Brazilian employees, the most retirees in this study kept their salaries matched to those of active workers in the same professional category and institution. Only eight retirees did not have salary parity with their active counterparts, thus they are unlikely to have influenced our results. Brazil, as most countries, has undergone significant changes in the rights and yields of retirement regulation, signaling growing losses of rights and advantages for future retirees 34 . Moreover, factors beyond work and retirement conditions, especially the level of social wellbeing prevailing in the country, could influence the degree of life satisfaction after retirement 35 . Most studies assessing the relation between retirement and life satisfction were conducted in highincome countries, such as the United States and Europe, and few were conducted in low- or middleincome countries, such as Brazil, where living conditions and social protection regimes are generally more unfavorable. 
The type of work, whether manual or not, can influence life satisfaction before and after retirement 36 , especially because manual workers tend to be low paid and have more strenuous tasks. Nevertheless, in our study, the adjustment by type of work has not changed the magnitudes of the associations between retirement and life satisfaction. Also, We found no evidence of statistical interaction between type of work and retirement variables. Differently from some studies 25,36, the associations between retirement and life satisfaction did not vary by gender as we had hypothesized. In fact, the life satisfaction average was similar in men and women ( $24.2 \pm 3.3$ and $23.9 \pm 3.5$, respectively). Although previous studies indicate that women and men differ regarding occupational prestige 37,38 , it is possible that gender differences in job status are less pronounced among civil servants from teaching and research institutions, explaining the absence of effect modification in the association between retirement and life satisfaction.

A great strength of our study was the use of a multidimensional construct of life satisfaction that allows for respondents to integrate and to weigh their satisfaction with physical health, economic status, housing, family relationships, and neighbor relationships regarding their own values 1 . Unlike other measures based on a single item and a limited period of time or specific domain 39,40, the Satisfaction With Life Scale is a short instrument that assesses an overall judgment of life satisfaction 40. Furthermore, this scale has been used worldwide in different cultures and has shown internal and test-retest reliability, as well as good psychometric properties across several populations 40,41,42,43,44. This study also presents other strengths, such as a large sample and the inclusion of a great number of potential confounders considered in the analysis, since retirement and life satisfaction have multiple and complex determining factors, and many are common or shared 45. Most studies on retirement and life satisfaction considered only sociodemographic factors in their analyses 9,31, and a smaller number included adjustments for behavioral and health factors 14,26,27,46. Furthermore, our results were adjusted for depression, a factor rarely included in previous studies, despite the evidence that depression can negatively affect one's quality of life 47 and anticipate retirement 48 . We excluded retirees for health reasons - who constituted a very small proportion of retirees - because their experience of retirement is likely to differ significantly from those who chose to retire because they reached the minimum age or length of employment required. Among individuals that retire because of health reasons, we cannot attribute life satisfaction after retirement to this transition, or to the health condition that preceded and triggered the retirement.

This study has also some limitations. Firstly, life satisfaction was not measured at baseline, therefore we do not know if life satisfaction of retirees was already higher at that time. Secondly, our results cannot be extrapolated to the general population or to future generations, as the studied sample represents the reality of work and retirement of Brazilian employees with stable jobs and better retirement regime than those in effect for the majority of the working force in Brazil. We must emphasize that, most ELSA-Brasil participants have high levels of education and hold prestigious and socially recognized jobs, besides stable working positions. Thus, they are likely to be more satisfied with their job experience, both before and after retirement, than the overall working population 49,50. For this reason, the mean levels of life satisfaction observed in this cohort cannot be extrapolated to other occupational groups. In this study, the four-category variable "type of work" was grouped into two categories (manual/not-manual), and this could result in residual confounding. To verify this, we compared the associations with life satisfaction using both variables (4 and 2-categories) and the magnitudes of the associations were similar. Thus, we maintained type of work as a binary variable in order to enhance the statistical power of the analyses. Finally, the survival bias is a potential concern in our results. It is known that greater life satisfaction is associated with longer lifespan ${ }^{4}$. In ELSABrasil, retiree participants at the baseline had higher mortality risk up to the second visit, than those who were not retired. However, this greater risk was totally explained by the higher mean age of the retirees as compared to the active individuals (data not shown). Thus, although survival might be an intrinsic issue, age was considered in the analysis and the survival effect is likely small.

Furthermore, recent changes in retirement rules set in place in Brazil to meet governments financial needs, have increased both the minimum age of retirement for men and women and the minimum employment length required before retirement for most of the workforce, including civil servants. These new rules are likely to affect the retirement experience and life satisfaction. Thus, the associations observed in our study cannot be extrapolated to the future generations of civil servant who will 
retire under the new and more constraining retirement regime. Moreover, we must emphasize that retirement conditions are deteriorating faster for workers outside the public sector, as social security rules are becoming more restricted and adverse to formally employed individuals. Even more worrying is the fact that retirement is out of reach for an immense group of precarious and informal workers in Brazil 51, widening and deepening the prevailing social inequalities.

Despite limitations, this analysis reinforces the literature regarding retirement and life satisfaction. Our results gain relevance as life satisfaction emerges as an significant indicator of successful aging ${ }^{52}$. Retirement is an important transition period in the ageing process. Its association with higher life satisfaction indicates that retirement can have positive effects on general health, functioning, and quality of life 52,53,54. Hence, our findings reinforce the significance of ensuring decent retirement as part of the policies aimed at promoting successful aging.

\section{Conclusions}

This study extends the existing literature by showing that retirement is associated with higher life satisfaction in a large cohort of civil servants from a middle-income country, particularly for the retirees that did not work afterwards. Although participants who retired $>8-15$ years presented the highest life satisfaction mean score, we found no clear pattern in the association between time since retirement and life satisfaction as compared to active employees. Life satisfaction after retirement is an important indicator of the level of social development for a country that is quickly aging, like Brazil. The increase in life satisfaction after retirement can attenuate potential challenges of aging for social development, indicating the valuing of citizens not only as those who directly generate income, but also well-being for the society at large. Life satisfaction after retirement certainly has a positive effect on health and the use of health services, decreasing the economic and social costs with the inexorable aging that the country is currently facing. However, cautious must be taken as retirement opportunities and benefits are changing, moving towards progressively lower benefits for newer generations of retirees, including civil servants. Thus, our results can serve as inputs for discussions among civil servants, public institutions and the society as a whole, and might also help collective as well as individual decisions related to retirement. 


\section{Contributors}

J. F. C. Rodrigues contributed to the study conception and design, data analysis and interpretation, and writing. S. M. Barreto and L. Giatti contributed to the study conception and design, data acquisition and analysis, and writing. R. H. Griep, M. J. M. Fonseca, and L. V. Camelo contributed to the data acquisition and analysis, writing, and review. All authors approved the final version of the manuscript.

\section{Additional informations}

ORCID: Jôsi Fernandes de Castro Rodrigues (0000-0001-6176-9129); Sandhi Maria Barreto (0000-0001-7383-7811); Rosane Harter Griep (0000-0002-6250-2036); Maria de Jesus Mendes da Fonseca (0000-0002-5319-5513); Lidyane do Valle Camelo (0000-0001-7471-7547); Luana Giatti (0000-0001-5454-2460).

\section{Acknowledgments}

The authors thank the staff and participants of the ELSA-Brasil study for their significant contributions.

\section{References}

1. Diener E, Emmons RA, Larsen RJ, Griffin S. The Satisfaction With Life Scale. J Pers Assess 1985; 49:71-5.

2. Diener E, Inglehart R, Tay L. Theory and validity of Life Satisfaction Scales. Soc Indic Res 2013; 112:497-527.

3. Ng ST, Tey NP, Asadullah MN. What matters for life satisfaction among the oldestold? Evidence from China. PLoS One 2017; 12:e0171799.

4. Diener E, Chan MY. Happy people live longer: subjective well-being contributes to health and longevity: health benefits of happiness. Appl Psychol Health Well-Being 2011; 3:1-43.

5. Instituto Brasileiro de Geografia e Estatística. Projeções da população: Brasil e unidades da Federação, revisão 2018. 2a Ed. Rio de Janeiro: Instituto Brasileiro de Geografia e Estatística; 2018.

6. Cho J, Lee A. Life satisfaction of the aged in the retirement process: a comparative study of South Korea with Germany and Switzerland. Appl Res Qual Life 2014; 9:179-95.

7. Guerson LRSC, França LHFP, Amorim SM. Satisfação com a vida em aposentados que continuam trabalhando. Paid Ribeirão Preto 2018; 28:1-8.

8. Kim JE, Moen P. Retirement transitions, gender, and psychological well-being: a lifecourse, ecological model. J Gerontol B Psychol Sci Soc Sci 2002; 57:P212-22.

9. Carlstedt AB, Brushammar G, Bjursell C, Nystedt P, Nilsson G. A scoping review of the incentives for a prolonged work life after pensionable age and the importance of "bridge employment". Work 2018; 60:175-89.

10. Gorry A, Gorry D, Slavov SN. Does retirement improve health and life satisfaction? Health Econ 2018; 27:2067-86

11. Hansson I, Buratti S, Johansson B, Berg AI. Beyond health and economy: resource interactions in retirement adjustment. Aging Ment Health 2019; 23:1546-54.

12. Warr P, Butcher V, Robertson I, Callinan M. Older people's well-being as a function of employment, retirement, environmental characteristics and role preference. Br J Psychol 2004; 95:297-324.

13. Diener E, Lucas RE, Oishi S. Advances and open questions in the science of subjective well-being. Collabra Psychol 2018; 4:15.

14. Hershey DA, Henkens K. Impact of different types of retirement transitions on perceived satisfaction with life. Gerontologist 2014; 54:232-44

15. Horner EM. Subjective well-being and retirement: analysis and policy recommendations. J Happiness Stud 2014; 15:125-44.

16. Heybroek L, Haynes M, Baxter J. Life satisfaction and retirement in Australia: a longitudinal approach. Work Aging Retire 2015; 1:166-80.

17. Ribeiro PCC, Almada DSQ, Souto JF, Lourenço RA. Permanência no mercado de trabalho e satisfação com a vida na velhice. Ciênc Saúde Colet 2018; 23:2683-92. 
18. Calasanti TM. Gender and life satisfaction in retirement: an assessment of the male model. J Gerontol B Psychol Sci Soc Sci 1996; 51B: S18-29.

19. Pinquart M, Sorensen S. Gender differences in self-concept and psychological well-being in old age: a meta-analysis. J Gerontol B Psychol Sci Soc Sci 2001; 56:P195-213.

20. Aquino EML, Barreto SM, Bensenor IM, Carvalho MS, Chor D, Duncan BB, et al. Brazilian Longitudinal Study of Adult Health (ELSABrasil): objectives and design. Am J Epidemiol 2012; 175:315-24.

21. Schmidt MI, Duncan BB, Mill JG, Lotufo PA, Chor D, Barreto SM, et al. Cohort profile: Longitudinal Study of Adult Health (ELSABrasil). Int J Epidemiol 2015; 44:68-75.

22. World Health Organization. Global recommendations on physical activity for health. Geneva: World Health Organization; 2010.

23. Nunes MA, Alves MGM, Chor D, Schmidt MI, Duncan BB. Adaptação transcultural do CIS-R (Clinical Interview Schedule-Revised Version) para o português no Estudo Longitudinal de Saúde do Adulto (ELSA). Rev HCPA \& Fac Med Univ Fed Rio Gd do Sul 2011; 31:487-90.

24. Neter J, Kutner M, Wasserman W. Applied linear statistical models. 4th Ed. New York: McGrawHill/Irwin; 1996.

25. Boehs S, Bardagi M, Silva N. Trabalho, aposentadoria e satisfação de vida em aposentados de uma multinacional. Rev Psicol Organ Trab 2019; 19:653-61.

26. Dingemans E, Henkens K. Involuntary retirement, bridge employment, and satisfaction with life: a longitudinal investigation. J Organ Behav 2014; 35:575-91.

27. Dingemans E, Henkens K. Working after retirement and life satisfaction: cross-national comparative research in Europe. Res Aging 2019; 41:648-69.

28. Xue B, Head J, McMunn A. The impact of retirement on cardiovascular disease and its risk factors: a systematic review of longitudinal studies. Gerontologist 2020; 60:e367-77.

29. Wang M. Profiling retirees in the retirement transition and adjustment process: examining the longitudinal change patterns of retirees' psychological well-being. J Appl Psychol 2007; 92:455-74.

30. Kesavayuth D, Rosenman RE, Zikos V. The dynamic effects of retirement on well-being. Pullman: School of Economic Sciences, Washington State University; 2016.

31. Schmälzle M, Wetzel M, Huxhold O. Pathways to retirement: are they related to patterns of short- and long-term subjective well-being? Soc Sci Res 2019; 77:214-29.

32. Gall TL, Evans DR, Howard J. The retirement adjustment process: changes in the well-being of male retirees across time. J Gerontol B Psychol Sci Soc Sci 1997; 52B:P110-7.

33. Hansson I, Buratti S, Thorvaldsson V, Johansson B, Berg AI. Changes in life satisfaction in the retirement transition: interaction effects of transition type and individual resources. Work Aging Retire 2018; 4: 352-66.
34. Brasil. Proposta de Emenda à Constituição no 6 de 2019. Modifica o sistema de previdência social, estabelece regras de transição e disposições transitórias, e dá outras providências. http://www.camara.gov.br/proposicoesWeb/ prop_mostrarintegra? codteor $=1712459 \&$ filename $=$ PEC-6-2019 (accessed on 20/ Aug/2020).

35. Richardson S, Carr E, Netuveli G, Sacker A. Country-level welfare-state measures and change in wellbeing following work exit in early old age: evidence from 16 European countries. Int J Epidemiol 2019; 48:389-401.

36. Iwatsubo Y, Derriennic F, Cassou B, Poitrenaud J. Predictors of life satisfaction amongst Retired people in Paris. Int J Epidemiol 1996; 25:160-70.

37. Navarro M, Salverda W. Earner position and job and life satisfaction: do contributions to the household income have the same effect by gender and occupations? J Happiness Stud 2019; 20:2227-50.

38. Choi S, Kyungwon L. Life satisfaction, occupation and gender. J Asian Sociol 2020; 49:57-74.

39. Cantril H. The pattern of human concerns. New Brunswick: Rutgers University Press; 1965.

40. Pavot W, Diener E. Review of the satisfaction with life scale. Psychol Assess 1993; 5:164-72.

41. Hinz A, Conrad I, Schroeter ML, Glaesmer $\mathrm{H}$, Brähler E, Zenger M, et al. Psychometric properties of the Satisfaction with Life Scale (SWLS), derived from a large German community sample. Qual Life Res 2018; 27:1661-70.

42. Bagherzadeh $M$, Loewe $N$, Mouawad RG, Batista-Foguet JM, Araya-Castillo L, Thieme C. Spanish Version of the Satisfaction with Life Scale: Validation and Factorial Invariance Analysis in Chile. Span J Psychol 2018; 21:E2.

43. Dirzyte A, Perminas A, Biliuniene E. Psychometric properties of Satisfaction with Life Scale (SWLS) and Psychological Capital Questionnaire (PCQ-24) in the Lithuanian Population. Int J Environ Res Public Health 2021; 18:2608.

44. Silva BNS, Campos LA, Silva WR, Marôco J, Campos JADB. Propriedades psicométricas da Satisfaction with Life Scale em adultos jovens brasileiros. Cad Saúde Pública 2021; 37:e00169020.

45. Siguaw JA, Sheng X, Simpson PM. Biopsychosocial and retirement factors influencing satisfaction with life: new perspectives. Int J Aging Hum Dev 2017; 85:332-53.

46. Carr DC, Moen P, Perry Jenkins M, Smyer M. Postretirement life satisfaction and financial vulnerability: the moderating role of control. J Gerontol B Psychol Sci Soc Sci 2020; 75:849-60.

47. Sirgy MJ. The psychology of quality of life: hedonic well-being, life satisfaction, and eudaimonia. 2nd Ed. New York: Springer; 2012.

48. Lee J, Smith JP. Work, retirement, and depression. J Popul Ageing 2009; 2:57-71.

49. Chacko TI. Job and life satisfactions: a causal analysis of their relationships. Acad Manage J $1983 ; 26: 163-9$. 
50. Hofmann J, Gander F, Ruch W. Exploring differences in well-being across occupation type and skill. Transl Issues Psychol Sci 2018; 4:290-303.

51. Lavinas L, Araújo ED. Reforma da previdência e regime complementar. Braz J Polit Econ 2017; 37:615-35.

52. Maher JP, Conroy DE. Daily life satisfaction in older adults as a function of (in)activity. J Gerontol B Psychol Sci Soc Sci 2015; 72:593602.
53. Calderón-Larrañaga A, Vetrano DL, Welmer A-K, Grande G, Fratiglioni L, Dekhtyar S. Psychological correlates of multimorbidity and disability accumulation in older adults. Age Ageing 2019; 48:789-96.

54. Saadeh M, Welmer A-K, Dekhtyar S, Fratiglioni L, Calderón-Larrañaga A. The role of psychological and social well-being on physical function trajectories in older adults. J Gerontol A Biol Sci Med Sci 2020; 75:1579-85. 


\section{Resumo}

O estudo buscou examinar se a aposentadoria está associada a maior satisfação com a vida e se a associação difere de acordo com gênero e tipo de ocupação. Trata-se de uma análise transversal de 13.645 servidores públicos, entre ativos e aposentados, avaliados na segunda visita da coorte Estudo Longitudinal de Saúde do Adulto (ELSA-Brasil, 2012-2014). Foram excluídos os aposentados por motivo de saúde. As variáveis independentes eram: (1) situação ocupacional atual (não aposentado, aposentado); (2) engajamento em trabalho depois da aposentadoria (não aposentado, aposentado e trabalhando, aposentado e não trabalhando); (3) tempo desde a aposentadoria (não aposentado, > 0-3, > 3-8, > 8-15, > 15 anos). A satisfação com a vida foi obtida com a Escala de Satisfação com a Vida. As associações foram estimadas por regressão linear multivariada. Depois de ajustar para indicadores sociodemográficos e de saúde, a satisfação com a vida era mais alta entre aposentados ( $\beta=0,50$, IC95\%: 0,32; 0,68) comparados com os não aposentados. Os aposentados que não estavam trabalhando ( $\beta=0,56$, IC95\%: 0,33; $0,78)$ pareciam mais satisfeitos que aqueles que estavam trabalhando ( $\beta=0,46$, IC95\%: 0,26; 0,66) e os não aposentados. A satisfação com a vida era maior entre aqueles que estavam aposentados: $>0-3$ anos ( $\beta=0,57$, IC95\%: 0,33; 0,81), > 8-15 anos $(\beta=0,66$, IC95\%: 0,34; 0,98) e > 15 anos $(\beta=0,51$, IC95\%: 0,27; 0,74), comparados aos ativos. Essas associações não foram modificadas por gênero ou tipo de ocupação. Nesta coorte brasileira, servidores públicos aposentados de instituições de ensino e pesquisa pareciam mais satisfeitos com a vida em comparação com os servidores ativos. Os resultados sugerem que a satisfação com a vida pode variar de acordo com o tempo desde a aposentadoria e se o individuo continua trabalhando depois, embora as associações se sobreponham.

Aposentadoria; Trabalho; Satisfação Pessoal; Estudos Transversais

\section{Resumen}

El objetivo del estudio fue examinar si la jubilación está asociada con una satisfacción vital mayor y si esta asociación difiere por sexo, así como naturaleza de la ocupación. Se trata de un análisis transversal con 13.645 empleados públicos activos y jubilados, que participaron en la consulta 2 de la cohorte Estudio Longitudinal de Salud de Adultos (ELSA-Brasil, 2012-2014). Se excluyeron a jubilados que tuvieran problemas de salud. Las variables explicativas fueron: (1) estatus ocupacional actual (no jubilado, jubilado); (2) compromisos laborales tras la jubilación (no jubilado, jubilado y trabajando, jubilado y no trabajando); (3) tiempo desde la jubilación (no jubilado, > 0-3, > 3-8, > 8-15, > 15 años). La satisfacción vital procede de la Escala de Satisfacción con la Vida. Las asociaciones se estimaron mediante una regresión lineal múltiple. Tras considerar indicadores sociodemográficos y de salud, satisfacción vital fue mayor para los jubilados ( $\beta=0,50,95 \% \mathrm{CI}: 0,32 ; 0,68)$ que para los no jubilados. Los jubilados que no estaban trabajando $(\beta=0,56,95 \% \mathrm{CI}: 0,33 ; 0,78)$ parecieron más satisfechos que los que estaban trabajando ( $\beta=0,46,95 \% \mathrm{CI}: 0,26 ; 0,66)$, así como que quienes no estaban jubilados. La satisfacción vital fue mayor entre quienes se jubilaron: $>0-3$ años $(\beta=0,57,95 \% \mathrm{CI}: 0,33 ; 0,81),>8-15$ años $(\beta=0,66,95 \% C I: 0,34 ; 0,98), y>15$ años $(\beta=$ $0,51,95 \% \mathrm{CI}: 0,27 ; 0,74)$ si se compara con trabajadores activos. Estas asociaciones no fueron modificadas por género o naturaleza ocupacional. En esta cohorte brasileña, los empleados públicos retirados de la enseñanza e instituciones de investigación parecían más satisfechos con sus vidas que las personas activas. Los resultados sugieren que la satisfacción vital puede variar con el tiempo tras la jubilación, así como en las personas que siguen trabajando después, a pesar de las dimensiones producidas por la superposición de asociaciones.

Jubilación; Trabajo; Satisfacción Personal; Estudios Transversales
Submitted on $11 / \mathrm{Feb} / 2021$

Final version resubmitted on 14/Jul/2021

Approved on 28/Aug/2021 